Kuronen, M., P. Lintunen \& T. Nieminen (toim.) 2017. Näkökulmia toisen kielen puheeseen Insights into second language speech. AFinLA-e. Soveltavan kielitieteen tutkimuksia 2017 / n:o 10. 3-17.

\author{
Mikko Kuronen ${ }^{1}$, Pekka Lintunen ${ }^{2} \&$ Tommi Nieminen $^{3}$ \\ ${ }^{1}$ Jyväskylän yliopisto, ${ }^{2}$ Turun yliopisto, ${ }^{3}$ Itä-Suomen yliopisto
}

\title{
Suullisen kielitaidon ja ääntämisen tutkimuksesta soveltavan kielentutkimuksen alalla Suomessa
}

AFinLA's research network for Speech and Spoken Language Research was established in 2014. This is the first thematic publication from the network. This introductory article introduces and classifies the other articles in this collection. In addition, we examine earlier AFinLA publications from the preceding four decades and evaluate the extent of pronunciation or spoken language research in AFinLA's publication series. In our analysis, we noticed that studies related to pronunciation or spoken language research formed ca. $12 \%$ of the total volume of published articles. There has been a slight proportional decrease in number during the decades. Spoken language studies have been more common than studies focusing on pronunciation. The target languages have been most commonly either Finnish or English. The main focus has often been on learning or assessing foreign language skills, but studies focusing on the teaching of pronunciation or spoken language have so far been very rare in Finland.

Avainsanat: ääntäminen, suullinen kielitaito, oppiminen, opetus

Keywords: pronunciation, spoken communication, learning, teaching 


\section{Johdanto}

Puheen ja puheentutkimuksen teemaverkosto perustettiin AFinLAn alaisuuteen keväällä 2014. Kuvauksen mukaisesti teemaverkosto on tarkoitettu puheesta, suullisesta kielitaidosta (puheen tuottamisesta ja ymmärtämisestä), prosodiasta, fonetiikasta, ääntämisestä tai muista puhutun kielen osa-alueista kiinnostuneille soveltavan kielitieteen tutkijoille. Käsillä oleva artikkelikokoelma on ensimmäinen teemaverkoston toiminnan perusteella aikaan saatu julkaisu. Kirjoituskutsussa pyydettiin kirjoittajia tarttumaan empiirisesti aiheeseen, joka liittyisi puheeseen tai suullisen kielitaidon tai ääntämisen oppimiseen ja joka olisi kiinnostava suomalaisessa kontekstissa. Artikkeleita saapui runsaasti, ja ne vastasivat hyvin niin teemaverkoston kuin kirjoituskutsummekin teemaa. Monet tämän kokoelman artikkeleista pohjautuvat AFinLAn syyssymposiumeissa pidettyihin temaattisiin työpajoihin.

Tässä katsausartikkelissamme esittelemme aluksi kartoituksen Suomen soveltavan kielitieteen yhdistyksen, AFinLAn, vuosikirjojen ja erikoisjulkaisujen puheen tutkimusta, tarkemmin suullista kielitaitoa ja ääntämistä, käsittelevistä tutkimuksista vuosivälillä 1977-2016. Katsauksen tarkoituksena on antaa kuva siitä, paljonko ja millaista tutkimusta vuosikirjoissa ja erikoisjulkaisuissa on ollut suullista kielitaitoa ja ääntämistä koskien. AFinLAn julkaisut ovat vain yksi monista kanavista, joissa puheen tutkimusta Suomessa julkaistaan, eikä katsauksemme siten anna tyhjentävää kuvaa maassamme tehdystä puhutun kielen tutkimuksesta. Otoksemme riittää kuitenkin antamaan käsityksen vallinneista tutkimusperinteistä ja painopisteistä soveltavan kielentutkimuksen alalla.

Artikkelimme jälkimmäisessä osassa esittelemme käsillä olevan erikoisjulkaisun tutkimukset. Jälkimmäinen osa antaa kuvan siitä, millaisia kysymyksiä soveltava puheentutkimus nykyisin käsittelee.

\section{Suullisen kielitaidon ja ääntämisen tutkimus AFinLAn julkaisuissa 1977-2016}

Artikkeliamme varten kartoitimme AFinLAn vuosikirjat ja erikoisjulkaisut vuosina 1977-2016. Tarkasteltu 40 vuoden ajanjakso mahdollistaa tutkimuspainotusten muutosten analyysin. Kartoituksemme perustuu ensisijaisesti otsikkotason analyysiin, mutta tarvittaessa perehdyimme myös itse tutkimuksiin. Sekä ensikielen (L1) että toisen (= vieraan) kielen (L2) puheeseen keskittyvät tutkimukset luokiteltiin alaluokkiin suullinen kielitaito tai ääntäminen. Määrittely 'puheeseen keskittyvä tutkimus' ei ollut aina helppo, koska lukuisissa tutkimuksissa käsitellään eri tavoin vuorovaikutusta, viestintää tai diskurssia (engl. interaction, communication, discourse). Kriteerimme puhutun kielen 
tutkimukselle olivat, että (i) sen aineisto on (vähintäänkin osin) puhuttua kieltä ja (ii) aineistoa käsitellään (vähintäänkin osin) puhutun kielen näkökulmasta ja sen erityisominaisuuksiin keskittyen. Emme luokitelleet tutkimusta puhutun kielen tutkimukseksi, ellei tutkimuksessa tehty eroa kirjallisen ja suullisen kielen välille (eli tutkimus esimerkiksi käsitteli jotakin vuorovaikutuksellista ilmiötä mutta ei suoranaisesti puhetta) tai tutkimuksen pääpaino oli kirjoitetussa kielessä. Rajauksemme ei toki sulkenut pois esimerkiksi vuorovaikutukseen keskittyviä tutkimuksia, mutta niiden luokittelu puhetta käsitteleviksi tutkimuksiksi edellytti, että vuorovaikutuksen tarkastelu kohdistui nimenomaan johonkin puhutun kielen piirteeseen, kuten Leila Käännän tutkimuksessa (ks. luku 3 alla) ääntämisen opetukseen luokkahuonetilanteessa.

Puhutun kielen tutkimukset määriteltiin tarkemmin opetusta, oppimista ja arviointia tai kielitaidon mittaamista koskeviksi. Myös alaluokittelu tuotti joissain tapauksissa vaikeuksia, koska samassa tutkimuksessa saatettiin käsitellä kahta tai (harvemmin) kaikkia kolmea alaluokkaa. Tällaisissa tapauksissa annoimme tutkimukselle alaluokan sen sisällöllisen painopisteen mukaan. Luokitteluun liittyvien rajanvetojen vuoksi kartoituksemme tuloksia ei tule tarkastella artikkelin eikä edes prosentin tarkkuudella, vaikka sen käytännön syistä teemmekin alla.

Suullista kielitaitoa tai ääntämistä käsitteleviä tutkimuksia oli 89 kaikkiaan 724:sta AFinLAn julkaisuissa raportoiduista tutkimuksista, mikä tekee 12,3\% tutkimuksen kokonaismäärästä (taulukko 1). Kielentutkimus jaetaan joskus kahteen pääluokkaan, kirjalliseen ja suulliseen. Tämän lisäksi on tutkimusta, joka käsittelee kumpaakin pääluokkaa tai ei erityisesti kumpaakaan; myös tämä kartoitus perustuu näihin luokkiin. Täten ei voi odottaakaan, että suullisen kielitaidon ja ääntämisen tutkimus muodostaisi puolta tutkimuksen kokonaismäärästä. Silti vain reilun kymmeneksen osuutta voi pitää pienenä, koska suullisen kielitaidon merkitys on esimerkiksi kielen oppimisessa suuri. Suullisen kielitaidon vähäinen tutkimus AFinLAn julkaisuissa heijastelee näkemyksemme mukaan perinnettä, joka on leimannut kielitiedettä yleisemminkin: lähtökohtana on useimmiten ollut kirjallinen tuotos, kieliopin tai rakenteiden käyttö ja hallinta kirjoitetussa kielessä (vrt. Linell 2005: the written language bias). Vaikka tarkasteluvälimme onkin hieman eri, osuutta voi varovasti verrata esimerkiksi Karlssonin (1998, 2003) selvitykseen kielitieteiden tohtorinväitöskirjoista, jonka mukaan Suomessa valmistui 413 kielitieteellistä väitöskirjaa vuosina 1978-2001. Alakohtaisissa jaotteluissa todetaan vuosina $1972-2001^{1}$ ilmestyneen 19 fonetiikan, puheviestinnän tai logopedian väitöskirjaa, joiden teeman voi ajatella suoraan liittyvän puhuttuun kieleen (19/453 eli $4 \%$ ). Suomi (2004) tarkensi lukumäärää huomauttamalla, että monet suulliseen kielitaitoon liittyvät väitöskirjat tehdään vieraiden kielten oppiaineisiin tai tutkinto suoritetaan ulkomaisissa yliopistoissa. Suomi lisää 12 foneettista väitöskir-

$1 \quad$ Alakohtaisissa erittelyissä on lähteissä eri vuosijako kuin kokonaissummissa. 
TAULUKKO 1. Suullisen kielitaidon ja ääntämisen tutkimus AFinLAn julkaisuissa 19772016. Taulukossa annetaan tutkimusten määrä pää- ja alaluokissa. Kullekin luokalle annetaan myös prosenttiosuus tutkimuksen kokonaismäärästä.

\begin{tabular}{|c|c|c|c|c|c|c|c|c|}
\hline & \multicolumn{2}{|c|}{ opetus } & \multicolumn{2}{|c|}{ oppiminen } & \multicolumn{2}{|c|}{$\begin{array}{c}\text { arviointi / } \\
\text { mittaaminen }\end{array}$} & \multicolumn{2}{|c|}{ yhteensä } \\
\hline & $\mathrm{n}$ & $\%$ & $n$ & $\%$ & $\mathrm{n}$ & $\%$ & $n$ & $\%$ \\
\hline $\begin{array}{l}\text { suullinen } \\
\text { kielitaito }\end{array}$ & 10 & 1,4 & 38 & 5,2 & 20 & 2,8 & 68 & 9,4 \\
\hline ääntäminen & 2 & 0,3 & 14 & 1,9 & 5 & 0,7 & 21 & 2,9 \\
\hline yhteensä & 12 & 1,7 & 52 & 7,2 & 25 & 3,5 & 89 & 12,3 \\
\hline
\end{tabular}

jaa tarkastelemallemme ajanjaksolle. Koska ääntämiseen tai suulliseen kielitaitoon liittyviä väitöskirjoja tehdään myös muihin oppiaineisiin ja yhteismäärä on siis oletettavasti hieman näitä numeroita korkeampi, AFinLAn julkaisuissa ilmestyneiden aihepiirin tutkimusten suhteellisen osuuden voidaan tulkita vastaavan hyvin ääntämisen ja suullisen kielitaidon osuutta suomalaisessa kielitieteellisessä tutkimuksessa laajemminkin, jos lukumäärää verrataan esimerkiksi väitöskirjojen teemoihin.

Ääntämistä on tutkittu vain vähän (2,9\% kaikista AFinLAn julkaisujen tutkimuksista), ja aivan erityisen vähän on tutkittu sen opetusta: 0,3\% kaikista tutkimuksista (taulukko 1). Mitätöntä osuutta selittää osaltaan näin rajatun alueen kapeus, sillä ääntäminen on itsessään vain eräs suullisen kielitaidon osa-alue. Siltikin osuus on hämmästyttävän pieni, joten tutkimusaluetta ei ilmeisesti ole pidetty tärkeänä. Tulos heijastelee toisaalta sitä, että ääntämisen opetuksen tutkimus - esimerkiksi eri menetelmien vertailu - on haastavaa (vrt. Derwing \& Munro 2015: 77-108). Se edellyttää seurantaa, kontrolliryhmää tai -ryhmiä, oppimiseen vaikuttavien tekijöiden kontrollia sekä mahdollisesti myös foneettisten menetelmien hallintaa. Lisäksi ääntämiseen keskittyvää opetusta annetaan vähemmän kuin kirjalliseen ja yleiseen suulliseen kielitaitoon keskittyvää opetusta, mikä vaikeuttaa opetusryhmien ja -menetelmien vertailua.

Suomalaisena erityispiirteenä tilanteeseen on voinut vaikuttaa puheen ilmiöihin erikoistuneen fonetiikan oppiaineen jatkuvasti horjahdellut asema yliopistoissa. Foneettiset tutkimuspainotukset ja menetelmien hallinta eivät aina ole olleet valtavirtaa. Fonetiikka lakkautettiin oppiaineena Jyväskylän yliopistosta 1990-luvun alkupuolella, Tampereen ja Oulun yliopistoissa sillä on kaiken aikaa ollut henkilömäärältään niukat resurssit ja Turun yliopistossa sen tilannetta ovat haastaneet erilaiset hallinnolliset muutokset kuten katkokset professoritasoisissa työtehtävissä. Käytännössä vain Helsingin yliopistossa fonetiikalla on säilynyt pysyvä ja suhteellisen vakaa asema koko tarkastellun ajan. 
TAULUKKO 2. Suullisen kielitaidon ja ääntämisen tutkimusten kohdekielet julkaisuissa.

\begin{tabular}{lr}
\hline kohdekieli & $\mathrm{Ikm}$ \\
\hline englanti & 18 \\
suomi & 17 \\
ranska & 3 \\
saksa & 3 \\
venäjä & 3 \\
ruotsi & 2 \\
kielestä riippumaton & 43 \\
\hline
\end{tabular}

Toisaalta ääntämisen opetuksen tutkiminen on kansainvälisestikin ollut vähäistä (mm. Norris \& Ortega 2000; Derwing \& Munro 2005; Tergujeff 2013), vaikkakin se paraikaa vaikuttaa olevan hienoisessa nousussa (Derwing 2010). Ääntämisen opettamisen ja oppimisen vähäistä tutkimusta selittänee myös se, että foneettisia menetelmiä hallitsevien tutkijoiden mielenkiinto on ollut paremminkin ensikielessä ja sen murteissa kuin toisen kielen puheessa. Derwing ja Munro (2005: 379) toteavat ääntämisen tutkimisesta kansainvälisesti ja erityisesti englannin kieltä koskien, että se on ollut marginalisoitua soveltavan kielitieteen kentällä. Kartoituksemme näyttää, että näin voimme todeta tilanteesta Suomessakin.

Myös suullisen kielitaidon opetuksen tutkimus on ollut vähäistä $(1,4 \%$, taulukko 1), ja syyt siihen ovat luultavasti samansuuntaiset kuin ääntämisen opetuksen osalta. Suullisen kielitaidon oppimista on tutkittu selvästi enemmän (5,2 \%). Arviointia ja mittaamista on tutkittu hiukan enemmän kuin opetusta sekä ääntämisen että suullisen kielitaidon osalta (taulukko 1). Yhteenlaskettuna tavallisinta on ollut oppimislähtöinen tutkimus (7,2\%), sen jälkeen arviointi ja mittaaminen (3,5\%) ja viimeisenä opetus (1,7\%).

Jaoimme tutkimukset myös kohdekielen mukaan (taulukko 2). Kielikohtaisia tutkimuksia oli 46 , kun taas 43 tutkimusta oli kielestä riippumattomia. Huomattava osa tutkimuksista on ollut siis sellaisia, joissa ei käsitellä suoraan jotain tiettyä kieltä. Kielikohtaisista tutkimuksista valtaosa on käsitellyt englantia tai suomea.

Mikäli jaamme kartoituksemme kolmeen liki yhtä suureen aikaväliin 197789, 1990-2000 ja 2001-16, näemme, että suullisen kielitaidon osuus AFinLAn tutkimusten kokonaismäärästä ei ole ajan saatossa kasvanut vaan päinvastoin hienoisesti laskenut (kuvio 1). Kaikissa luokissa alin lukema on vuosivälillä 2001-2016 arviointia ja mittaamista lukuun ottamatta. Kun otetaan huomioon kartoituksen tarkkuuteen liittyvät rajoitukset, vähäisille muutoksille ei pidä antaa liian suurta painoa. Selvää kuitenkin on, että suullisen kielitaidon ja ääntämisen osuus tutkimuksen kokonaismäärästä ei ole ainakaan kasvanut 


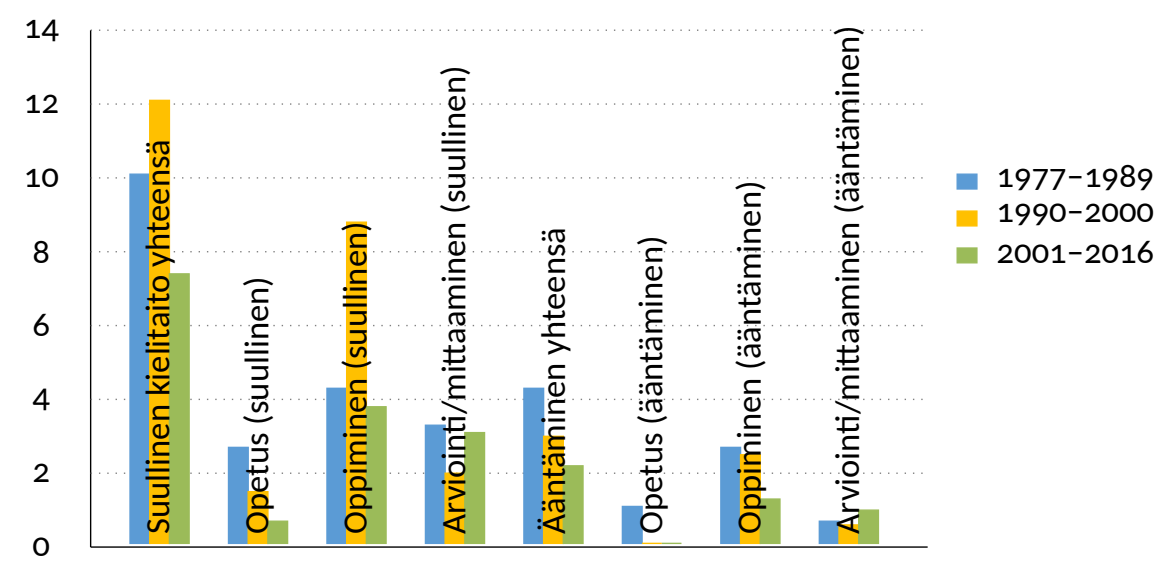

KUVIO 1. Suullisen kielitaidon ja ääntämisen tutkimus AFinLAn julkaisuissa vuosiväleillä 1977-1989, 1990-2000 ja 2001-2016.

tarkasteltavana ajanjaksona. Ääntämisen opetuksen tutkimisesta ei ole julkaisuja lähes koko aikana. Olematonta osuutta 1990-2000 ja 2001-2016 ei selitä ainakaan se, että aihetta olisi tutkittu tyhjentävästi jo aiemmin. Myös suullisen kielitaidon opettamisen tutkimus on ollut hyvin vähäistä ja pienintä viimeisellä ajanjaksolla. Suullisen kielitaidon oppimisen tutkimuksessa tapahtui selvä nousu 1990-luvulla, joka nyttemmin on taittunut. Suullisen kielitaidon painoarvon kasvu opetuksessa näkyy opetussuunnitelmissa 2000-luvulla (vrt. LOPS 2003, 2015) ja myös siten, että lukiossa on nykyisin suulliseen viestintään keskittyviä toisen kotimaisen/vieraan kielen kursseja (vrt. Muutos LOPSiin 2009; ks. myös Ruoho 2011). Ainakaan vielä suullisen kielitaidon painoarvon kasvu opetuksessa ei kuitenkaan tunnu näkyvän tutkimuksessa määrällisesti. Sen kartoitus kuitenkin näyttää, että opetuksen, oppimisen ja arvioinnin kysymykset ovat kiinnostaneet soveltavan kielitieteen tutkijoita jossain määrin koko kartoituksen ajan myös suullisen kielitaidon alueella (vrt. Kalaja ym. 2013).

Tiivistäen kartoituksemme osoittaa, että (i) suullinen kielitaito ja ääntäminen eivät ole olleet vahvasti edustettuina AFinLAn tuotannossa, (ii) suullisen kielitaidon ja ääntämisen tutkimukset eivät ole suhteelliselta määrältään nousussa vaan päinvastoin ne vaikuttavat olevan hienoisessa laskussa ja (iii) erityisen vähän on ollut tutkimusta suullisen kielitaidon ja ääntämisen opetuksesta. On perusteltua olettaa, että suullisen kielitaidon ja ääntämisen opettamisen tutkimuksen vähyys heijastuu puutteina kieltenopettajien koulutuksessa: Koska aihetta on tutkittu vähän, on yliopistojen opetushenkilökunnankin sitä koskeva tieto puutteellista. Puutteiden vuoksi merkittävä osa kielten opettajista kokee, ettei heillä ole riittäviä valmiuksia opettaa ääntämistä. He eivät yksinkertaisesti tiedä, millaisin menetelmin sitä voi opettaa $(\mathrm{mm}$. Huh- 
tamäki \& Zetterholm tässä julkaisussa; Moilanen 2014). Tämä saattaa johtaa siihen, että ääntämisen opetusta laiminlyödään tai opetus jää implisiittiseksi eikä kehitä oppijan ääntämistietoisuutta tai -motoriikkaa eteenpäin (Lintunen 2005, 2014). Pahimmillaan ääntämisharjoitukset saatetaan ohittaa kokonaan. Opetusmenetelmiä vertailevan ja oppimistuloksiin keskittyvän tutkimuksen vähyys vaikuttaa leimaavan oppimisen tutkimusta laajemminkin kuin vain kielenoppimisen alueella ( $\mathrm{mm}$. Eklund 2000). Myös tieto siitä, mikä ääntämisessä on ymmärtämisen ja vieraan korostuksen kannalta tärkeää, on puutteellista tutkimuksen vähyyden vuoksi (vrt. Kuronen \& Tergujeff tässä julkaisussa).

AFinLAn Puheen ja puheentutkimuksen teemaverkosto perustettiin edistämään puhutun kielen ja suullisen kielitaidon ja ääntämisen tutkimusta sekä tukemaan tutkijoiden verkostoitumista. Kartoituksemme perusteella teemaverkostolle on ollut selvä tarve. Uskomme, että käsillä oleva julkaisu auttaa osaltaan edistämään puheen tutkimusta soveltavan kielentutkimuksen alalla ja tässä teemanumerossa julkaistavat tutkimukset saavat jälleen uusia tutkijoita tarttumaan aihepiirin haasteisiin.

\section{Käsillä olevan julkaisun tutkimukset}

Tämä AFinLAn erikoisjulkaisu keskittyy puhutun kielen tutkimukseen. Julkaisun kaikki tutkimukset käsittelevät joko suullista kielitaitoa tai ääntämistä opettamisen, oppimisen tai arvioinnin näkökulmasta. Julkaisu koostuu 13 tutkimuksesta, joissa kaikissa pääpaino on toisessa kielessä vähintäänkin niin, että toista kieltä tarkastellaan suhteessa ensikieleen. Tutkimuksista neljä keskittyy suulliseen kielitaitoon ja yhdeksän ääntämiseen (taulukko 3). Kuten taulukko 3 osoittaa, tutkimukset lisäävät tietoa jaottelun jokaisessa kategoriassa. Useat tutkimuksista ovat kielikohtaisia, vaikka tulokset voivatkin olla yleistettävissä muihin kieliin. Neljä artikkelia voidaan laskea kielestä riippumattomiksi. Kielikohtaiset tutkimukset jakautuvat siten, että suomeen kohdistuu neljä, ruotsiin kolme ja venäjään kaksi artikkelia.

Kun artikkeleissa käytettyjä metodeja tarkastelee päämenetelmän mukaan, viidessä tutkimuksessa on käytetty kuuntelukokeita (syntyperäiset tai

TAULUKKO 3. Tämän teemajulkaisun artikkelit tutkimusalueittain.

\begin{tabular}{lrrrr}
\hline & & & $\begin{array}{c}\text { arviointi / } \\
\text { mittaaminen }\end{array}$ & yhteensä \\
\hline suullinen kielitaito & 1 & 1 & 2 & 4 \\
ääntäminen & 3 & 2 & 4 & 9 \\
yhteensä & 4 & 3 & 6 & 13 \\
\hline
\end{tabular}


ei-syntyperäiset kuulijat) ja kolmessa on mitattu oppimista (akustisesti, kuulonvaraisesti tai sanaston kannalta). Lisäksi teemajulkaisumme artikkelien menetelminä on opetusmenetelmän testaus, opetusmenetelmien vertailu, opetuksen havainnointi sekä opettajien haastattelu tai kysely, ja yksi artikkeli on lähestymistavaltaan teoreettinen.

Seuraavassa esittelemme tutkimukset ryhmitellen ne kartoituksemme luokkiin. Esittely noudattaa julkaisumme sisällysluetteloa järjestäen tutkimukset ryhmiin (i) suullisen kielitaidon/ääntämisen opettaminen, (ii) suullisen kielitaidon/ääntämisen oppiminen ja (iii) suullisen kielitaidon/ääntämisen arviointi ja mittaaminen.

\subsection{Suullisen kielitaidon ja ääntämisen opetuksen tutkimukset}

Tutkimuksista neljä käsittelee suullisen kielitaidon tai ääntämisen opettamista (Heikkola \& Alisaari, Huhtamäki \& Zetterholm, Kääntä, Spita \& Björklund). Juuri opettamista on tutkittu aiemmin hyvin vähän, ja julkaisun tutkimukset ovatkin arvokas lisä tälle alitutkitulle alueelle. Tutkimukset ovat metodologisesti erilaisia: opetusmenetelmiä verrataan keskenään eri opetusryhmissä, opetusmenetelmää testataan, opetusta havainnoidaan tai opettajien kokemuksia kartoitetaan kyselyin ja haastatteluin.

Leena Maria Heikkola ja Jenni Alisaari selvittävät tutkimuksessaan, kuinka kolme erilaista ääntämisen opetuksessa käytettävää menetelmää - laulaminen, laulujen kuuntelu ja laulun sanojen rytmikäs toistaminen - vaikuttavat suomenoppijoiden ääntämisen kehittymiseen. Oppijat osallistuivat neljä viikkoa kestäneelle suomen kurssille, jonka aikana ääntämistä opetettiin yllä mainituilla menetelmillä. Oppijoiden ääntämistä kurssin alussa ja lopussa arvioi kaksi kuulijaraatia: tulevat S2- eli suomi toisena kielenä -opettajat sekä tulevat luokanopettajat. Tulosten mukaan alkeiskurssin oppijoilla tapahtui merkittävää kehitystä ääntämisessä, kun puolestaan hiukan edistyneempien oppijoiden kohdalla edistyminen ei ollut yhtä suoraviivaista. Laulun sanojen rytmikäs toistaminen vaikutti olevan menetelmistä tehokkain: se oppijaryhmä, jonka opetuksessa käytettiin tätä menetelmää, kehittyi eniten kohdekielisen ääntämisen suuntaan. S2-opettajat arvioivat vierasta aksenttia lievemmin kuin luokanopettajat. Kirjoittajat arvelevat tämän johtuvan siitä, että S2-opettajilla on enemmän kokemuksia vieraalla aksentilla puhutusta suomesta.

Martina Huhtamäki ja Elisabeth Zetterholm keskittyvät tapaustutkimuksessaan ääntämisopetukseen ruotsi vieraana kielenä -tilanteissa. He vertailivat aikuisopiskelijoille suunnattua ääntämisopetusta Suomessa ja Ruotsissa. Aineisto kerättiin kahdeksaa opettajaa haastattelemalla ja oppituntia seuraamalla. Tavoitteena oli myös verrata, kuinka se, mitä opettajat sanovat ja mitä he tunneilla tekevät, vastaavat toisiaan. Molemmissa maissa opettajat korostivat ääntämisen opettamisen keskeistä asemaa ruotsin opetuksessa. Opetta- 
jat kuitenkin kokivat, etteivät he tienneet monia opetusmetodeja ääntämisen opetukseen. Suurin osa havaitusta ääntämisopetuksesta luokkahuonetilanteissa oli implisiittistä ja integroitu esimerkiksi kieliopin tai sanaston opetukseen. Ruotsalaisissa luokkahuonetilanteissa havaittiin enemmän eksplisiittistä ääntämisen opetusta kuin suomalaisissa. Maiden välillä on ymmärrettävästi yleisestikin eroja, koska Suomessa ruotsin vähemmistöasema tekee opettamisesta erilaista ja usein haasteellisempaa kuin Ruotsissa. Opettajien haastattelussa esiin tuomat mielipiteet vastasivat hyvin heidän toimintaansa luokkahuonetilanteissa. Kirjoittajat korostavat, että opettajankoulutuksessa on syytä kiinnittää huomiota ääntämisopetuksen metodeihin ja opettaa tulevia opettajia vertaamaan opettamaansa kieltä oppilaiden erilaisiin äidinkieliin.

Leila Kääntä keskittyy tutkimuksessaan suomenkielisten englanninoppijoiden ääntämisongelmiin luokkahuonetilanteissa. Hän tutki keskusteluntutkimuksen menetelmin, miten oppilaat ilmaisevat kohdanneensa ääntämisongelmia lukiessaan englantia ääneen. Tehtävän tarkoituksena ei ollut keskittyä suoraan ääntämiseen vaan tarjota mahdollisuus ääntämisen harjoitteluun muun toiminnan rinnalla. Laajemmasta aineistosta valikoitui kymmenen esimerkkiä, joissa oppilas kohtaa ääntämisongelman. Kääntä keskittyy analyysissaan erityisesti korjausten aloituksiin: suoriin kysymyksiin, erilaisten ääntämistapojen yritykseen ja lukemisen keskeyttämiseen. Näillä keinoilla oppilaat koettivat saada opettajalta apua oikeaan ääntämistapaan. Opettajan ja oppilaan interaktion tutkiminen selventää, millaista ääntämisopetukseen liittyvä luokkahuoneinteraktio on. Havainnoista on hyötyä opettajankoulutuksessa. Ne myös osoittavat, kuinka luokkahuoneharjoituksia voidaan käyttää vieraan kielen ääntämisen parantamiseen.

Irina Spita ja Martina Björklund tarkastelevat opetuskokeiluun perustuvassa tutkimuksessaan, kuinka venäjän kielen L2-puhujat oppivat nk. emotiivista morfologiaa, tarkemmin diminutiivisuffikseja, alkeiskurssilla, joka perinteisestä opetuksesta poiketen eteni pragmaattis-semanttisten taitojen hallinnasta sananhallinnan suuntaan. Tämä tarkoittaa sitä, että diminutiivisia sanamuotoja esiteltiin ja harjoiteltiin $\mathrm{mm}$. toiminnallisin dialogein, jotka osoittivat konkreettisesti, millaisia asenteita ja tunteita eri sanamuotojen käyttö välittää. Diminutiivimuotoja harjoiteltiin esimerkiksi siten, että opiskelijat perehtyivät venäläisten ravintoloiden ruokalistoissa esiintyviin diminutiivimuotoihin, ja tämän jälkeen harjoittelivat näiden muotojen käyttöä dialogeissa ja roolileikeissä. Kun opiskelijat tunnistivat diminutiivimuodot ja niiden merkityksen, kurssilla tarkasteltiin, millainen merkitys diminutiivimuotojen poistamisella ja/tai korvaamisella on erilaisissa sanoissa. Kirjoittajien mukaan opetuskokeilun tulokset olivat hyviä: emotiivisten muotojen käyttö edisti positiivisen ilmapiirin syntymistä luokkahuoneessa ja oppimistuloksetkin olivat hyviä. Oppijoiden motivaatiota vaikutti edistävän myös se, että opetuksen lähtökohtana oli paremminkin luonnollinen, arjessa käytettävä kieli kuin kankeahko oppikirjakieli. 


\subsection{Suullisen kielitaidon ja ääntämisen oppimisen tutkimukset}

Kirjamme tutkimuksista kolme keskittyy suullisen kielitaidon ja ääntämisen oppimiseen (Heinonen, Peltonen, Salminen). Näissä keskitytään joko ymmärrettävyyteen, sujuvuuteen tai vieraaseen korostukseen.

Henna Heinosen tutkimuksessa tarkastellaan ensikieleltään suomenkielisten lukiolaisten puhutun ruotsin ymmärrettävyyttä sekä mahdollisten kuulijaa tai puhujaa koskevien taustatekijöiden vaikutusta arvioon. Tuloksista käy ilmi, että kuulijan taustalla (esim. kielitaustalla, sukupuolella ja iällä) ei näyttäisi olevan vaikutusta. Yleisesti ottaen lukiolaisten tuottamaa ruotsia saattoi ymmärtää, mutta se saattoi vaatia kuulijalta keskittymistä. Puhujan ruotsin kielen käyttö vapaa-aikana vaikutti myönteisesti puheen ymmärrettävyyteen, kun taas yllättäen puhujan viimeisimmän ruotsin arvosanan ja puheen ymmärrettävyyden välinen korrelaatio oli negatiivinen. Jälkimmäisen Heinonen arvioi voivan olla tekemisissä ääntämistä koskevan tietoisuuden kanssa: ääntämistä koskevan tiedon lisääntyminen voi vaikuttaa haitallisesti sujuvan puheen tuottamiseen.

Pauliina Peltonen yrittää tutkimuksessaan murtaa vieraalla kielellä puhumisen sujuvuutta koskevan tutkimuksen perinteiset rajat ja tarkastella puhetta yhteistoiminnallisen vuorovaikutuksen kautta. Hän tarkastelee kahden yläkoululaisparin puhetta ongelmanratkaisutehtävässä ja analysoi tuloksia. Tulosten mukaan toistot (engl. other-repetitions) mahdollistavat puhujan sujuvuutta antamalla hänelle lisäaikaa kielen käsittelyyn. Toistoilla voi myös hakea puhekumppanin vahvistusta omalle ilmaisulle, jolloin ne lisäävät viestinnän koheesiota. Samoin koheesiota kohentavat täydennykset (engl. collaborative completions), mutta niiden avulla myös ylläpidetään sujuvuutta, mikä ei aiemmissa tutkimuksissa ole noussut esiin.

lina Salmisen artikkelin kohteena ovat suomalaisille oppijoille perinteisesti vaikeina mainostetut venäjän ässät, jotka foneettisesti jakautuvat sibilantteihin ja affrikaattoihin. Hän tarkastelee eksplisiittisen ääntämisopetuksen vaikutusta oppimistuloksiin niin tuottamisen kuin havaitsemisen osalta sekä kontrastiivisen kielitieteen mahdollisuuksia ääntämisopetuksen kehittämisessä. Hänen tuloksistaan käy ilmi, että reseptiivisen ja produktiivisen osaamisen välillä näkyy vallitsevan yhteys joidenkin äänteiden kohdalla muttei läheskään kaikkien. Eri testikertojen tulosten kirjavuus ja aineiston pienuus vaikeuttaa lopullisten johtopäätösten tekoa - mikä viittaa lisätutkimuksen tarpeeseen mutta eksplisiittisen ääntämisopetuksen hyödyn tekijä katsoo käyneen jo tässäkin aineistossa ilmi. Jatkoa ajatellen hän korostaa, että tuottamisen harjoittelemisen lisäksi aikaa olisi varattava puhujalle vieraiden äänteiden havaitsemiseen ja tunnistamiseen. 


\subsection{Suullisen kielitaidon ja ääntämisen arviointi tai mittaaminen}

Pääosa kirjamme tutkimuksista - kuusi artikkelia - käsittelee suullisen kielitaidon/ääntämisen arviointia tai mittaamista (Honko, Olkkonen \& Peltonen, Kallio ym., Kuronen \& Tergujeff, Toivola \& Ullakonoja, Uzal ym.). Lähtökohtana näissä tutkimuksissa on - Hongon sekä Olkkosen ja Peltosen tutkimuksia lukuun ottamatta - kuulijoiden arviot toisen kielen ääntämisen hyvyydestä tai ymmärrettävyydestä. Muutamissa tutkimuksista arvioita tarkastellaan suhteessa puheen akustisiin tai rakenteellisiin piirteisiin.

Mari Honko tarkastelee tutkimuksessaan puhutun kielen leksikaalista diversiteettiä kouluikäisten lasten kielessä. Tutkimuksessa selvitetään, poikkeaako puhutun kielen sadutettujen kertomusten leksikaalinen diversiteetti kirjoitetun kielen kertomusten leksikaalisesta diversiteetistä. Lisäksi Honko selvittää, onko puhuttujen kertomusten leksikaalisessa diversiteetissä systemaattisia eroja riippuen lapsen sanaston hallinnan yleistasosta, kielitaidon yleistasosta, ensikielestä, sukupuolesta tai iästä. Aiempien tutkimusten tapaan Hongonkin tutkimuksessa leksikaalinen diversiteetti oli korkeampaa kirjoitetussa kuin puhutussa kielessä. Kielitaidon yleistason ja sanaston hallinnan yleistason yhteys leksikaaliseen diversiteettiin osoittautui kuitenkin heikoksi ja epälineaariseksi. Honko toteaakin eräänä johtopäätöksenään, että leksikaalista diversiteettiä ei voi tarkastellun aineiston perusteella pitää riittävän tarkkana menetelmänä silloin, kun tarkoituksena on arvioida yksilötason kielitaidon tai tarkemmin sanastollisten taitojen tasoa.

Heini Kallio, Juraj Šimko, Ari Huhta, Reima Karhila, Martti Vainio, Erik Lindroos, Raili Hildén ja Mikko Kurimo tarkastelevat artikkelissaan temporaalisten piirteiden (artikulaationopeus, hiljaisten ja täytettyjen taukojen määrä ja korjaukset ja/tai toistot) suhdetta arvioituun taitotasoon. Puhujina tutkimuksessa on suomalaisia lukiolaisia, jotka puhuvat ruotsia toisena kielenään. Verrokkipuhujina on ensikieleltään (suomen)ruotsalaisia lukiolaisia. Puhenäytteet ovat lukupuhunnasta ja puolispontaanista puheesta, ja arvioijina on seitsemän koulutettua arvioijaa. Tulosten mukaan tietyillä temporaalisilla piirteillä on yhteys puhujan arvioituun taitotasoon, mutta piirteiden merkitys riippuu puhemateriaalista: korjauksia, toistoja ja lyhyitä taukoja siedetään paremmin puolispontaanissa puheessa kuin lukupuhunnassa. Korkea artikulaationopeus ennusti korkeampaa taitotason arviointia kummassakin materiaalityypissä, kun taas täytettyjen taukojen korkea suhteellinen määrä ennusti alhaista arviota taitotasosta. Arvioijien välillä oli kuitenkin eroja siinä, millainen merkitys temporaalisilla piirteillä oli taitotason arvioinnille. Tutkimuksen eräs johtopäätös onkin, että tulisi kehittää menetelmiä arvioijien välisen vaihtelun vähentämiseksi erityisesti nk. korkean panoksen testeissä. Arvioijien profilointi ja siihen perustuva palaute arvioijille saattaisivat edistää arvioijien tietoisuutta eri foneettisista piirteistä ja parantaa heidän arviointisuoritustaan. 
Mikko Kuronen ja Elina Tergujeff tutkivat artikkelissaan prosodian vaikutusta aksentin vahvuuden arviointiin. He pyysivät syntyperäisiä ruotsin kielen puhujia arvioimaan kielenoppijoiden tuottamaa ruotsia. Tutkimus keskittyi ruotsin tooniaksentteihin eli sävelkorkoihin ja puherytmin muutoksiin. Aineistona oli 30 ääneen luettua virkettä, joissa pitäisi olla tietty tooniaksentti ja pääpaino virkkeen loppupuolella. Virkkeet tuotti kuusi kielenoppijaa ja kaksi syntyperäistä ruotsin puhujaa. Arvioijina oli 53 syntyperäistä ruotsin puhujaa. Tulosten mukaan normista poikkeava puherytmi aiheutti vaikutelman vahvemmasta vierasperäisestä aksentista. Tooniaksenttien taas ei havaittu vaikuttavan merkittävästi aksenttiarvioihin. Kuronen ja Tergujeff tulivat siihen johtopäätökseen, että prosodian opetuksessa kannattaa painottaa erityisesti puherytmiä ja muita prosodisia piirteitä tooniaksenttien sijaan.

Sanna Olkkonen ja Pauliina Peltonen tarkastelevat toisen kielen sujuvuudelle annettuja määritelmiä kirjallisuuden valossa ja pyrkivät yhdistämään kaksi tähän asti varsin erillisinä pysytellyttä näkökulmaa, kognitiivisen ja puhetuotoksen sujuvuuden. Näkökulmat liittyvät erilaisiin tutkimusperinteisiin eikä niitä siksi ole tavattu vertailla keskenään. Näkökulmat yhdistämällä kirjoittajat katsovat voivansa taata aiempaa kattavamman kuvan aiheeseen liittyvästä tutkimuksesta, erityisesti auttaa selittämään, miksei joidenkin sujuvuuteen liitettyjen piirteiden välille ole kyetty löytämään yhteyttä. Artikkelillaan kirjoittajat pyrkivät kannustamaan muita tutkijoita ylittämään perinteiset rajat ja suuntautumaan tutkimuskysymykseen monialaisesti.

Minnaleena Toivola ja Riikka Ullakonoja keskittyvät artikkelissaan venäläisen aksentin tunnistamiseen suomessa vieraana kielenä. Näytteet $(n=80)$ olivat ääneen luettuja lauseita äidinkieleltään suomalaisilta puhujilta ja venäläisiltä suomen kielen oppijoilta. Oppijat tuottivat lauseita eri vaiheissa kuuden kuukauden oleskeluaan Suomessa. Kuuntelutestin arvioijat olivat syntyperäisiä suomen puhujia, ei-syntyperäisiä suomen opiskelijoita ja ei-syntyperäisiä kuuntelijoita, jotka eivät opiskelleet suomea. Tulosten perusteella arvioijaryhmät erosivat toisistaan. Paremmin suomea osaavat ryhmät erottivat venäjänkieliset puhujat helpommin syntyperäisistä. Arvioijaryhmät sanoivat kiinnittäneensä puherytmiä enemmän huomiota muihin prosodisiin ja segmentaalisiin piirteisiin. Kirjoittajat toivovat, että tutkijat testaisivat tulevaisuudessa enemmän vieraan aksentin tunnistamista pitkäkestoisissa tutkimuksissa.

Melike Uzal, Erkki Komulainen ja Olli Aaltonen tutkivat kuulijan taustatekijöiden ja tehtävätyypin vaikutusta aksentin vahvuuden arvioinnissa. Kohdekielenä heillä oli suomi vieraana kielenä. Kuulijoiden taustamuuttujista kontrolloitiin sukupuolta, ikää, opetuskokemusta, aiempia kontakteja vieraskielisiin suomen puhujiin ja asumista pääkaupunkiseudulla. Tehtävätyyppeinä olivat sanaparit, virkkeiden ääneen lukeminen ja spontaani puhe. Tehtävät tuottivat 31 syntyperäistä suomen puhujaa ja 40 kielenoppijaa. Kuuntelutestiin osallistui 66 syntyperäistä suomen puhujaa, jotka arvioivat kuulemansa vieraan ak- 
sentin. Tulosten mukaan kuulijoiden taustamuuttujilla ei näyttänyt olevan vaikutusta aksentin arviointiin. Analyysissa havaittiin myös, että näytteen pituus vaikutti aksenttiarvioon: pidempi näyte arvioitiin yleensä heikommin. Samoin spontaanit näytteet arvioitiin heikommiksi kuin kontrolloidummat näytteet.

\section{Loppupäätelmiä}

Kartoituksemme osoittaa, että suullisen kielitaidon ja ääntämisen tutkimus ei ole ollut runsasta AFinLAn tuotannossa aikavälillä 1977-2016: vain reilu kymmenes julkaistun tutkimuksen kokonaismäärästä on käsitellyt näitä teemoja. Suullisen kielitaidon ja ääntämisen osuus ei ole myöskään kasvanut aikavälillä, vaan päinvastoin jonkin verran laskenut. Kartoituksen tuloksia tarkasteltaessa tulee tosin muistaa, että huomattava osa suullisen kielitaidon ja ääntämisen tutkimuksista julkaistaan muilla foorumeilla kuin AFinLAn julkaisuissa, eikä kartoitus siten anna kattavaa kuvaa suullisen kielitaidon ja ääntämisen tutkimuksesta maassamme (jälkimmäisestä ks. tarkemmin Kautonen ym. 2016). Se antaa kuitenkin käsityksen tutkimusalueen suhteellisesta osuudesta AFinLAn julkaisuissa ja laajemmin soveltavan kielentutkimuksen alalla Suomessa.

Soveltavan puheentutkimuksen painopiste on ollut ja on yhä toisen kielen puheessa: kaikki tämänkin julkaisun artikkeleista käsittelevät L2-puhetta. L2-tutkimus antaa kuitenkin samalla tietoa myös L1-puheesta, koska ensikieli toimii lähes aina vertailukohtana L2-puheelle. L2-ääntämisen tutkimuksessa on siirrytty yhä selvemmin ääntämisen oppimisen mittaamisesta siihen, miten kuulijat arvioivat L2-ääntämistä ymmärrettävyyden, sujuvuuden tai vieraan korostuksen kannalta (mm. Levis \& LeVelle 2010a; Munro 2010). Painopisteen siirtyminen kuulijahavaintoon näkyy tämänkin julkaisun tutkimuksissa. Ymmärrettävyyden ja sujuvuuden tutkimista puoltaa se, että kommunikatiivisesti toimivaa ääntämistä pidetään nykyään tärkeämpänä kuin mahdollisimman vähäistä vierasta korostusta (mm. Levis 2005; Thorén 2009; Heinonen tässä julkaisussa). Suullisen kielitaidon testaus on yleistynyt ja tekee tuloaan mm. suomalaiseen ylioppilastutkintoon (Huhta \& Hildén 2016), ja tämänkin vuoksi tarvitaan tietoa siitä, miten kuulija ymmärtää ja kokee L2-puhetta. Kommunikatiivisesti toimivan ääntämisen painotukseen voi kuitenkin suhtautua myös kriittisesti, mikäli se tarkoittaa sitä, että ääntämisen opettamisen tavoitteita tietoisesti lasketaan (vrt. Kjellin 2002). Ääntämisen opetusta koskien opettajan ja oppijan tavoitteet eivät aina tunnukaan kohtaavan (Porter 1999), mistä saattaa olla haitallisia seurauksia opettamisen tehokkuuden näkökulmasta.

Riittävän hyvä suullinen kielitaito vieraissa kielissä on tärkeää lukuisissa ammateissa (EK-tiedustelu 2010), ja se on myös keskeistä tai ainakin mielletään keskeiseksi mahdollisimman sujuvan maahanmuuttajien kotoutumisen kannalta (mm. Boyd 2004; Tarnanen \& Pöyhönen 2011). Näistäkin syistä ään- 
tämisen ja suullisen kielitaidon tutkiminen ja tutkimustulosten hyödyntäminen opettajakoulutuksessa ja opetuksessa on tärkeää.

Vaikka kartoituksemme näyttää, että suullisen kielitaidon ja ääntämisen tutkimus ei ole ollut AFinLAn tuotannossa määrällisesti runsasta, erikoisjulkaisumme kuitenkin osoittaa, että tutkimusta tehdään monissa yliopistoissa, tutkijat ovat verkostoituneet kiitettävästi ja Suomessa tehtävä tutkimus seuraa yllä kuvattuja kansainvälisen tutkimuksen painopisteitä.

\section{Lähteet}

Boyd, S. 2004. Utländska lärare i Sverige: attityder till brytning. Teoksessa K. Hyltenstam \& I. Lindberg (toim.) Svenska som andraspråk: i forskning, undervisning och samhälle. Lund: Studentlitteratur, 419-436.

Derwing, T. M. 2010. Utopian goals for pronunciation teaching. Teoksessa J. Levis \& K. LeVelle (toim.) Proceedings of the 1st pronunciation in second language learning and teaching conference: lowa State University, Sept. 2009. Ames (lowa): lowa State University, 24-37.

Derwing, T. M. \& M. J. Munro 2005. Second language accent and pronunciation teaching: a research-based approach. TESOL Quarterly, 39 (3), 379-397. DOI: 10.2307/ 3588486.

- 2015. Pronunciation fundamentals: evidence-based perspectives for L2 teaching and research. Amsterdam: John Benjamins.

EK-tiedustelu 2010. Työelämässä tarvitaan yhä useampia kieliä: EK:n henkilöstö- ja koulutustiedustelu 2009. Helsinki: Elinkeinoelämän keskusliitto.

Eklund, H. 2000. Vart är pedagogikforskningen på väg? ämnesområden och forskningsmönster i svenska doktorsavhandlingar under en femårsperiod. Pedagogisk Forskning i Sverige, 5 (2), 131-150.

Huhta, A. \& R. Hildén 2016. Kielitutkinnot ja muu laajamittainen kielitaidon arviointi Suomessa. Teoksessa A. Huhta \& R. Hildén (toim.) Kielitaidon arviointitutkimus 2000-luvun Suomessa. AFinLA-e: soveltavan kieliteteen tutkimuksia 9. Jyväskylä: Suomen soveltavan kielitieteen yhdistys AFinLA, 3-26. https://journal.fi/afinla/ article/view/60844.

Kalaja, P., H. Dufva, K. Mäntylä \& A. Pitkänen-Huhta 2013. AFinLA: the Finnish association of applied linguistics. European Journal of Applied Linguistics, 1 (1), 162-173. DOI: 10.1515/eujal-2013-0008.

Karlsson, F. 1998. Kielitieteiden tohtorinväitöskirjat Suomessa 1840-1997. Helsinki: Helsingin yliopisto.

- 2003. Kielitieteiden tohtorinväitöskirjat Suomessa 1902-2001: määrällisiä suuntauksia. Virittäjä, 107 (1), 68-76. https://journal.fi/virittaja/article/view/40238.

Kautonen, M., M. Kuronen \& R. Ullakonoja 2016. Studier i uttalsinlärning i finska, svenska och engelska: litteraturöversikt. Puhe ja kieli, 36 (3), 197-220. https : //journal.fi/pk/article/view/59010.

Kjellin, O. 2002. Uttalet, språket och hjärnan: teori och metodik för språkundervisningen. Uppsala: Hallgren \& Fallgren.

Levis, J. 2005. Changing contexts and shifting paradigms in pronunciation teaching. TESOL Quarterly, 39 (3), 369-377. DOI: 10.2307/3588485. 
Levis, J. \& K. LeVelle 2010a. Pronunciation and intelligibility: an overview of the conference. Teoksessa J. Levis \& K. LeVelle (toim.) Pronunciation and intelligibility: issues in research and practice: proceedings of the 2nd annual pronunciation in second language learning and teaching conference. Ames (lowa): lowa State University, 1-6.

Levis, J. \& K. LeVelle (toim.) 2010b. Pronunciation and intelligibility: issues in research and practice: proceedings of the 2nd annual pronunciation in second language learning and teaching conference. Ames (lowa): lowa State University.

Linell, P. 2005. The written language bias in linguistics: its nature, origins and transformations. London: Routledge.

Lintunen, P. 2005. Ääntäminen, tietoisuus ja oppiminen. Teoksessa K. Virta, K. Merenluoto \& P. Pöyhönen (toim.) Ainedidaktiikan ja oppimistutkimuksen haasteet opettajankoulutukselle. Turku: Turun yliopisto, 342-349.

- 2014. Ääntämisen oppiminen ja opettaminen. Teoksessa P. Pietilä \& P. Lintunen (toim.) Kuinka kieltä opitaan: opas vieraan kielen opettajalle ja opiskelijalle. Helsinki: Gaudeamus, 165-187.

LOPS 2003. Lukion opetussuunnitelman perusteet. Helsinki: Opetushallitus.

- 2015. Lukion opetussuunnitelman perusteet. Helsinki: Opetushallitus.

Moilanen, J. 2014. Auffassungen der Deutsch- und Schwedischlehrer über Ausspracheunterricht. Pro gradu -tutkielma. Jyväskylä: Jyväskylän yliopisto. http://urn.fi/ URN:NBN:fi:jyu-201403241394.

Munro, M. J. 2010. Intelligibility: buzzword or buzzworthy? Teoksessa J. Levis \& K. LeVelle (toim.) Pronunciation and intelligibility: issues in research and practice: proceedings of the 2nd annual pronunciation in second language learning and teaching conference. Ames (lowa): lowa State University, 7-16.

Muutos LOPSiin 2009. Nuorille tarkoitetun lukiokoulutuksen opetussuunnitelman perusteiden 2003 muuttaminen. Helsinki: Opetushallitus.

Norris, J. M. \& L. Ortega 2000. Effectiveness of L2 instruction: a research synthesis and quantitative meta-analysis. Language Learning, 50 (3), 417-528. DOI: 10.1111/ 0023-8333.00136.

Porter, D. 1999. Pronunciation. Teoksessa B. Spolsky (toim.) Concise encyclopedia of educational linguistics. Oxford: Pergamon, 647-652.

Ruoho, M. 2011. Svensklärares åsikter om, attityder till och erfarenhet av den muntliga kursen Tala och förstå bättre och övning av muntlig språkfärdighet. Pro gradu -tutkielma. Jyväskylä universitet. http://urn.fi/URN:NBN:fi:jyu-2011052510918.

Suomi, K. 2004. Foneettiset väitökset Suomessa. Virittäjä, 108 (4), 587-590. http: //urn.fi/URN:NBN:fi:ELE-1027889.

Tarnanen, M. \& S. Pöyhönen 2011. Maahanmuuttajien suomen kielen taidon riittävyys ja työllistymisen mahdollisuudet. Puhe ja kieli, 31 (4), 139-152. https://journal. fi/pk/article/view/4750.

Tergujeff, E. 2013. English pronunciation teaching in Finland. Jyväskylä Studies in Humanities 207. Jyväskylä: University of Jyväskylä. http://urn.fi/URN:ISBN:978951-39-5322-5.

Thorén, B. 2009. Rätt betoning gör dig förstådd. Språktidningen, 1/2009. 